\author{
Jerzy Maternicki \\ https://orcid.org/0000-0001-5132-2315 \\ Rzeszów
}

\title{
Konfederacja barska w myśli historycznej szkoły krakowskiej: Michał Bobrzyński i Anatol Lewicki
}

Zarys treści: Artykuł jest kontynuacją rozprawki autora pt. Joachim Lelewel i Józef Szujski: wizje konfederacji barskiej. Szczegółowej analizie poddano poglądy Michała Bobrzyńskiego i Anatola Lewickiego na konfederację barską, zaprezentowane w ich całościowych ujęciach dziejów Polski. Zwrócono uwagę na występujące pomiędzy nimi podobieństwa i różnice, a także relacje z wizjami Józefa Szujskiego oraz związki z polityką historyczną konserwatystów krakowskich.

The content outline: In this article, the author continues to discuss the topic with which he first dealt in an essay entitled Joachim Lelewel i Józef Szujski: wizje konfederacji barskiej. The article provides a detailed analysis of the views of the Bar Confederation as advanced by M. Bobrzyński and A. Lewicki in their interpretations of Polish history. In addition to showing both differences and similarities existing between the two accounts of the political movement in question. The author also aims to establish how the analysed views related to those held by J. Szujski and how they connected to the politics of history pursued by the Kraków conservatives.

Słowa kluczowe: myśl historyczna, szkoła historyczna krakowska, Michał Bobrzyński, Anatol Lewicki, konfederacja barska, liberum conspiro, polityka historyczna konserwatystów krakowskich

Keywords: historical thought, the Kraków school of history, Michał Bobrzyński, Anatol Lewicki, the Bar Confederation, liberum conspiro, the Kraków conservatives' politics of history

Wiemy od dawna, że historycy szkoły krakowskiej wypowiadali się o konfederacji barskiej krytycznie, jak dotąd jednak nie zwrócono należytej uwagi na to, że krytycyzm ten miał wiele odcieni, co więcej, ulegał nieraz daleko posuniętej ewolucji ${ }^{1}$.

${ }^{1}$ Por. J. Maternicki, Joachim Lelewel i Józef Szujski: wizje konfederacji barskiej, w: Сniльна спадщина. Річ Посполита обох народів в польській і украйнській історичній думиі ХІХ і XX ст. / Wspólne dziedzictwo. Rzeczpospolita Obojga Narodów w polskiej i ukraińskiej myśli historycznej XIX i XX w., red. W. Telwak, L. Łazurko, P. Sierżęga, Chersoń 2019, s. 77-104. 
Najdalej w krytyce konfederacji barskiej posunął się Michał Bobrzyński (1849-1935)²; w wydanych w 1879 r. Dziejach Polski w zarysie ${ }^{3}$ potępiał ją w sposób bezwzględny, nie znajdując dla niej żadnego, nawet najmniejszego usprawiedliwienia. Młodszy o 23 lata od Waleriana Kalinki i o 14 lat od Józefa Szujskiego, kształtował swój światopogląd w zupełnie innych warunkach politycznych niż wymienieni wyżej jego mentorzy. W przeciwieństwie do nich nie miał za sobą przeszłości konspiracyjnej czy powstańczej, dorastał już po upadku powstania styczniowego, w środowisku konserwatywnym, stojącym zdecydowanie na gruncie ugody z Austrią i wysuwającym na plan pierwszy pracę organiczną. Dał też temu wyraz w otwierającej jego Dzieje Polski $w$ zarysie dedykacji. Ofiarowując swoje dzieło dwunastu wymienionym $\mathrm{z}$ nazwiska luminarzom polskiego życia umysłowego (znaleźli się w tym gronie m.in. Adam Asnyk, Kazimierz Morawski, Stanisław Smolka i Wincenty Zakrzewski), pisał: „Należymy do tego pokolenia, które ocaliwszy się z ostatniej zawieruchy, dojrzawszy już po niej, mając w żywej

${ }^{2}$ Por. S. Estreicher, Michał Bobrzyński, Warszawa 1936 (odb. z „Przeglądu Współczesnego”); M. Handelsman, Bobrzyński jako uczony, „Przegląd Historyczny” 33, 1936, nr 1, s. 341-361; S. Kieniewicz, Tło historyczne „Dziejów Polski” Bobrzyńskiego, „Przegląd Historyczny” 37, 1947 [1948], s. 343-356; B. Krzemieńska-Surowiecka, Polemika wokół „Dziejów Polski w zarysie” Michała Bobrzyńskiego (w latach 1879-1890), „Zeszyty Naukowe Uniwersytetu Łódzkiego. Seria 1. Nauki Humanistyczno-Społeczne" 1956, nr 4, s. 107-130; K. Grzybowski, Szkoła historyczna krakowska. Michał Bobrzyński (1849-1935), w: Studia z dziejów Wydziału Prawa Uniwersytetu Jagiellońskiego, red. M. Patkaniowski, Kraków 1964, s. 163-186; W.M. Bartel, Michał Bobrzyński (1849-1935), w: Spór o historyczną szkołę krakowską. W stulecie Katedry Historii Polski UJ 1869-1969, red. C. Bobińska, J. Wyrozumski, Kraków 1972, s. 145-189; M.H. Serejski, A.F. Grabski, M. Bobrzyński i jego „Dzieje Polski w zarysie”, w: M. Bobrzyński, Dzieje Polski w zarysie, oprac. i wstęp M.H. Serejski, A.F. Grabski, Warszawa 1974, s. 5-34; J. Maternicki, Michał Bobrzyński wobec tzw. idei jagiellońskiej. Ewolucja poglądów i jej uwarunkowania, „Przegląd Humanistyczny” 1977, nr 12, s. 131-142 (toż w: tenże, Kultura historyczna dawna i wspótczesna. Studia i szkice, Warszawa 1979, s. 144-160); tenże, Michał Bobrzyński wobec „idei zachodniej”, „Przegląd Humanistyczny” 1992, nr 2, s. 79-96 (toż w: tenże, Historia jako dialog. Studia i szkice historiograficzne, Rzeszów 1996, s. 34-54); A. Skrzypek, Michał Bobrzyński jako organizator nauki i wydawca źródeł, „Kwartalnik Historyczny" 85, 1977, nr 3, s. 643-656; W. Łazuga, Michał Bobrzyński. Myśl historyczna a działalność polityczna, Warszawa 1982; tenże, Ostatni stańczyk. Michał Bobrzyński - portret konserwatysty, Poznań b.d.w. (wyd. 2, Toruń 2005); A.F. Grabski, Jeszcze o sporach wokót „Dziejów Polski $w$ zarysie”, w: tenże, Perspektywy przeszłości. Studia i szkice historiograficzne, Lublin 1983, s. 279-340; W. Kaute, Synteza dziejów Polski Michała Bobrzyńskiego, Katowice 1993; E. Cesarz-Maternicka, Chłopi i sprawa chłopska w „Dziejach Polski” Michała Bobrzyńskiego, w: Historia, społeczeństwo, wychowanie, red. J. Maternicki, M. Hoszowska, P. Sierżęga, Rzeszów 2003, s. 137-149; B. Klassa, Obraz szlachty w „Dziejach Polski w zarysie” Michała Bobrzyńskiego, w: Klio polska. Studia i materiały z dziejów historiografii polskiej, t. 4, red. A. Wierzbicki, Warszawa 2009, s. 57-79

${ }^{3}$ Była to w epoce popowstaniowej najbardziej głośna i poczytna synteza dziejów narodowych. Za życia autora wydana została czterokrotnie: w 1879 (wyd. jednotomowe), 1880-1881 (wyd. „znacznie zwiększone”, dwutomowe), 1887-1890 (jw.) i 1927-1931 (wyd. trzytomowe, obejmujące także historię porozbiorową). Synteza Bobrzyńskiego doczekała się także tłumaczenia na kilka języków obcych, m.in. czeski. Po II wojnie światowej jej pierwsze wydanie było w kraju kilkakrotnie wznawiane. 
pamięci jej wszystkie następstwa, postanowiło zerwać z tradycją ostatniego stulecia i nie w młodzieńczych porywach, ale w trzeźwej a wytrwałej pracy wewnętrznej szukać zbawienia i lepszej przyszłości”4.

Owa „zawierucha”, o której Bobrzyński wspominał i od której najwyraźniej się odcinał, to oczywiście nic innego jak powstanie styczniowe. Już zresztą wcześniej, w 1870 r., mając wówczas niespełna 21 lat, przyszły historyk wyrażał opinię, że: „Tylko pracą wewnętrzną spotęgować możemy siły żywotne narodu i przewyższyć $\mathrm{w}$ ten sposób wroga, a wtedy przyjdzie czas, że wróg ten albo sam padnie, albo my go dobijem"5. Był zagorzałym zwolennikiem stańczyków i chętnie się do tego przyznawał $^{6}$; z czasem - jak wiadomo - stał się jedną z czołowych postaci obozu konserwatywnego w Galicji.

Podobnie jak Szujski, przywiązywał do historii wielką wagę, uważał, że wywiera ona ogromny, czasami wręcz przemożny wpływ na świadomość i postawy polityczne ludzi ${ }^{7}$. Przeszłość „umiejętnie badana” dostarcza narodowi „programu”, a więc wskazuje mu drogi dalszego działania i rozwoju ${ }^{8}$. Historia była dla niego wielką skarbnicą doświadczeń politycznych. Wychodząc z tego założenia, pisał: „byłoby to największą ujmą przeszłości naszej, żeby ona niczego nie dowodziła, w niczym doświadczenia naszego politycznego nie zbogaciła, żeby polityka przeszłości nie miała i nie mogła być dla polityki dzisiejszej przestrogą i wskazówką"9

Autor Dziejów Polski w zarysie w Uwagach do pierwszego wydania tego dzieła mocno jednak podkreślał, że z „doświadczenia dziejów” trzeba „rozsądnie i trzeźwo korzystać" ${ }^{10}$. Był zdecydowanym przeciwnikiem „iluzji” romantycznych, opowiadał się za surowym rozrachunkiem z przeszłością. „Musimy - pisał - odsłonić w całej grozie skutki lekkomyślnych, na chwilowym uczuciu polegających porywów, ażeby, zachowując zapał, zbudzić w sobie zmysł polityczny, wyzyskanie warunków, męską energię wytrwania i pracy"11.

Kreśląc swój zarys dziejów Polski, historyk krakowski miał na względzie zarówno jej przeszłość, jak też teraźniejszość i przyszłość. Chodziło mu - podobnie

\footnotetext{
${ }^{4}$ M. Bobrzyński, Dzieje Polski w zarysie... (1974), s. 37-38.

5 Tenże, Kilka słów o Irydionie, rkps, cyt. za: W. Łazuga, Michał Bobrzyński. Myśl historyczna a działalność polityczna..., s. 28.

${ }^{6}$ W. Łazuga, Michał Bobrzyński. Myśl historyczna a działalność polityczna...

7 Szerzej na ten temat zob. J. Maternicki, Historia i życie narodu. Poglady i postawy historyków polskich XIX i XX w., Rzeszów 2009, s. 158 n.

${ }^{8}$ Por. M. Bobrzyński, Kilka słów o najnowszym ruchu na polu naszego dziejopisarstwa, w: Historycy o historii. Od Adama Naruszewicza do Stanisława Kętrzyńskiego 1775-1918, t. 1, oprac. M.H. Serejski, Warszawa 1963, s. 154 (pierwodruk w „Niwie” w 1877 r.).

9 Tenże, Przedmowa do drugiego wydania „Dziejów Polski w zarysie”, w: tenże, Szkice i studia historyczne, t. 1, Kraków 1922, s. 78-79.

10 Tenże, Dzieje Polski w zarysie... (1974), s. 408.

11 Tenże, Dzieje Polski w zarysie, wyd. 3, Warszawa 1881, cyt. za: tenże, Dzieje Polski w zarysie, t. 2, wyd. 4 uzup., Warszawa 1927, s. 312.
} 
jak Szujskiemu - o zerwanie z konspiracyjną i powstańczą tradycją, i skupienie wszystkich sił narodu na pracy organicznej ${ }^{12}$.

Rzutowało to, rzecz jasna, na ujęcie zarówno całości dziejów narodowych, jak też na ocenę wielu zjawisk i wydarzeń historycznych, m.in. konfederacji barskiej. Bobrzyński nie poświęcił jej zbyt wiele uwagi. Wzmianka o niej - w pierwszej edycji dzieła - nie wypełnia w całości nawet jednej strony: to zaledwie 8 zdań, 27 wierszy tekstu. Dla Lelewela konfederacja barska była „powstaniem” narodowym, Szujski, pisząc o niej, używał najczęściej terminu „ruch” (szlachecki), Bobrzyński mówił już tylko o „ruchawce”, do tego „niewyćwiczonej”. Słowa te dobrze oddają stosunek każdego z wymienionych wyżej historyków do wydarzeń lat 1768-1772. W przypadku Bobrzyńskiego był on - jak dalej zobaczymy - nacechowany dużą dozą lekceważenia, a nawet politycznej odrazy.

Wzmianka o konfederacji barskiej została przez Bobrzyńskiego zamieszczona w pierwszym wydaniu Dziejów Polski w zarysie, w ostatnim rozdziale tej książki, zatytułowanym Przewaga Rosji. Zupełna anarchia kończy się pierwszym rozbiorem $k_{r a j u}{ }^{13}$. Wypełniają ją nie tyle informacje rzeczowe, ile refleksje ogólne i oceny ${ }^{14}$.

Konfederacja barska - twierdził Bobrzyński - porwała się do „czynnego protestu”: „Przeciw przewadze Rosji, ale zarazem w obronie dawnego porządku religijnego i politycznego"15. Zaraz jednak historyk dodawał: „Konfederacja taka, jakkolwiek będziemy oceniali jej pobudki, nie mogła doprowadzić do celu. Ruchawka niewyćwiczona nie mogła nic skutecznego zdziałać przeciw regularnemu wojsku Rosji i tylko cały kraj naraziła na straszne spustoszenia i klęski"16.

Bardzo surowo osądzał Bobrzyński „program polityczny” konfederacji; był on „przeciwny reformie, oddalał od niej króla i wszystkich wytrawniejszych ludzi, którzy tylko w reformie i w poparciu rządu królewskiego nadzieję lepszej przyszłości widzieli” ${ }^{17}$. Autor Dziejów Polski w zarysie ubolewał, że „nie słuchano rad najpolityczniejszego wśród konfederatów Adama Krasińskiego, biskupa kamienieckiego, na koniec konfederacja zamiast zbliżyć się do rządu, skompromitowała się wobec Europy ogłoszeniem bezkrólewia i nieudolnym porwaniem króla z Warszawy z braku sił ostatecznie upadła"18.

12 Por. S. Kieniewicz, Tło historyczne „Dziejów Polski” Bobrzyńskiego..., s. 343 n. Szerzej na ten temat $\mathrm{w}$ wymienionych w przyp. 2 pracach Waldemara Łazugi.

${ }_{13}$ Pierwsze wydanie Dziejów Polski w zarysie zostało doprowadzone do 1772 r., dopiero w drugim wydaniu autor uwzględnił czasy późniejsze, doprowadzając swój wykład do $1795 \mathrm{r}$.

${ }^{14} \mathrm{M}$. Bobrzyński nie relacjonował przebiegu zdarzeń, podał tylko datę zawiązania konfederacji i wymienił z nazwiska cztery osoby, których działalność była związana z ruchem barskim: biskupa Adama Krasińskiego, Józefa Pułaskiego, Charles’a François Dumourieza i Józefa Stempkowskiego.

15 M. Bobrzyński, Dzieje Polski w zarysie... (1974), s. 394-395.

16 Tamże, s. 395.

17 Tamże.

18 Tamże. 
Wspomnieliśmy już wyżej, że w tekście Bobrzyńskiego poświęconym konfederacji niewiele było informacji rzeczowych. Odnotowywał historyk „straszny bunt chłopstwa”, jaki wybuchł na Ukrainie, który „dopiero oboźny koronny Stempkowski z wielką srogością przytłumił". Historyk krakowski nic nie napisał na temat genezy tego buntu, a także jego konsekwencji dla ruchu barskiego. Niewiele uwagi poświęcił też relacjom konfederatów ze światem zewnętrznym, napomykał jedynie, że wspierała ich „wysłaniem generała Dumourieza i drobnych posiłków” Francja, „kokietowała” zaś Austria, „zezwalając na utworzenie rady generalnej konfederackiej i na jej urzędowanie w mieście Białej na Śląsku"19. Generalność oceniał Bobrzyński bardzo krytycznie, podnosił, że w niej "nie mogło nigdy przyjść do zgodnego i jednolitego działania" ${ }^{20}$. W jego ocenie konfederacja - odrzucając współdziałanie z królem, występując przeciwko niemu - nie miała żadnych szans powodzenia, niejako z góry skazana była na porażkę.

Podobne tezy głosił Szujski w wydanej rok później (1880) Historii polskiej. Bobrzyński, pracując nad swoją syntezą w latach 1877-1879, nie mógł tej pracy znać, gdyż Szujski ukończył ją dopiero w pierwszych miesiącach 1880 r. W tej sytuacji zasadne wydaje się porównanie nakreślonego przez Bobrzyńskiego obrazu konfederacji barskiej z tym, jaki odnajdujemy w pierwszej syntezie Szujskiego, ściślej w czwartym jej tomie, wydanym w 1866 r. Różnica ogromna. Szujski, krytykując barszczan, z ogromnym jednak szacunkiem odnosił się do motywów ich działań, zwłaszcza ich walki z Rosją, chwalił ich też za odwagę, poświęcenie i bohaterstwo, dowodził, że konfederacja barska, choć przyczyniła się do pierwszego podziału Polski, to jednak była jednocześnie „kolebką nowego patriotyzmu polskiego". Bobrzyński postrzegał wydarzenia lat 1768-1772 w sposób - jeśli tak rzec można - jednowymiarowy, oceniał je jednoznacznie negatywnie. $W$ obrazie przez niego nakreślonym nie ma ani jednego jaśniejszego punktu, wszystko jest mocno przyczernione, ponure i przygnębiające.

Duże podobieństwa można natomiast dostrzec pomiędzy obrazami ruchu barskiego w Dziejach Polski w zarysie i w drugiej syntezie Szujskiego. Ale i tu zauważyć można pewne, drobne może, ale wymowne przecież różnice. Bobrzyński wypowiadał się o motywach działania konfederatów barskich bardzo powściągliwie, nie zastanawiał się nad tym, czy i w jakiej mierze były one szlachetne i godne szacunku. Szujski, nie tylko w 1866, ale także w 1880 r. podnosił, iż była ona skutkiem gwałtów rosyjskich i „naturalnego” na nie oburzenia. W ten sposób, jak się wydaje, wyraził swoje zrozumienie dla motywów działania barszczan. Druga różnica. U Bobrzyńskiego nie ma ani słowa o ich poświęceniu i bohaterstwie, nawet nazwisko najsławniejszego z nich - Kazimierza Pułaskiego - zostało przez

19 Tamże.

20 Tamże. 
autora całkowicie pominięte. Szujski w 1880 r. nie pisał o nim wprawdzie wiele, ale przecież wspominał o jego „walecznej” obronie Częstochowy.

Warto tu jeszcze zwrócić uwagę na fakt, że z czasem i sam Bobrzyński w kolejnych wydaniach swego dzieła rozjaśnił nieco swój ponury obraz konfederacji barskiej. Zmiany nie były może wielkie, ale niepozbawione znaczenia. $\mathrm{W}$ tym przypadku pierwszą edycję syntezy Bobrzyńskiego porównamy z jej czwartym wydaniem (z 1927 r.). Jak pamiętamy, w 1879 r. historyk pisał, że konfederacja barska „jakkolwiek będziemy oceniali jej pobudki, nie mogła doprowadzić do celu [podkr. J.M.]”. W 1927 r. była już mowa o tym, że konfederacja barska ,jakkolwiek będziemy oceniali szlachetniejsze z jej pobudek, nie mogła doprowadzić do celu [podkr. J.M.]”21. Dostrzeżenie owych „szlachetniejszych pobudek” zawiązania konfederacji było zmianą dość istotną, ocieplającą choć trochę wciąż jeszcze mocno przyczerniony jej obraz. W czwartym wydaniu swej syntezy Bobrzyński napisał: „Ruchawka niewyćwiczona, niekarna, występująca kolejno w różnych miejscowościach bez ogólnego planu, pomimo wielu czynów odwagi i męstwa partyzantów, jak Zaremba i Kazimierz Pułaski, nie mogła nic skutecznego zdziałać przeciw regularnemu wojsku Rosji oraz wojsku stojącemu przy królu [podkr. J.M.]"22. Także i w tym przypadku wzmianka o „wielu czynach odwagi i męstwa" konfederatów, w szczególności Józefa Zaremby i Kazimierza Pułaskiego, łagodziła nieco wciąż jeszcze przygnębiający obraz wydarzeń lat $1768-1772^{23}$.

Pierwsza edycja Dziejów Polski w zarysie miała także swą wersję szkolną, przygotowaną do druku i opublikowaną $\mathrm{w}$ tym samym roku co oryginał przez nauczyciela historii w renomowanym Gimnazjum św. Anny w Krakowie, Michała Chylińskiego (1856-1925) ${ }^{24}$. Był on uczniem Ksawerego Liskego i zajmował się

${ }^{21}$ M. Bobrzyński, Dzieje Polski w zarysie... (1927), s. 247.

22 Tamże.

${ }^{23}$ Obraz konfederacji barskiej w IV edycji Dziejów Polski $w$ zarysie był nieco bogatszy pod względem faktograficznym od pierwowzoru z $1879 \mathrm{r}$. Jedną z istotnych różnic było to, że w późniejszych edycjach Bobrzyński - nawiązując być może do Szujskiego - więcej uwagi poświęcił polityce Stanisława Augusta Poniatowskiego. Przypominał m.in., że po zawiązaniu konfederacji i wybuchu walk z wojskami rosyjskimi „Stanisław August z Czartoryskimi opierał się stale żądaniu Rosji ażeby stworzyć przeciwkonfederację i po stronie Rosji się oświadczyć, owszem przeciw Rosji u państw zachodnich szukał dyplomatycznej przynajmniej u nich opieki. Na próżno. Pomoc obca zawiodła [...]. Konfederacja zamiast zbliżyć się do rządu i siły swoje przez to znakomicie zwiększyć, pod wpływem magnatów, których pycha nie mogła ścierpieć na tronie rodaka, skompromitowała się wobec Europy ogłoszeniem bezkrólewia [...] i nieudanym porwaniem króla z Warszawy, i z wycieńczenia sił ostatecznie upadła"; tamże, s. 248. W czwartym wydaniu swego działa Bobrzyński podał też informację, że: „Wielu konfederatów wywieziono na Sybir, resztki zbiegły do Turcji i Francji"; tamże.

${ }^{24}$ Por. A. Beaupré, Chyliński Michał (1856-1925), w: Polski słownik biograficzny, t. 4, Kraków 1938, s. 13; A. Puszka, Nauczyciele historii i geografii państwowych szkół średnich w Galicji w okresie autonomii (1868-1914), Lublin 1999, s. 279; J. Maternicki, Złote lata historiografii polskiej we Lwowie, Rzeszów 2015, s. 106-107, 115, 120. 
historią nowożytną, w szczególności XVIII w. Politycznie związany był z obozem konserwatystów krakowskich. Wiele wskazuje na to, że przygotowując do druku szkolną adaptację syntezy Bobrzyńskiego, Chyliński korzystał z rękopisu tego dzieła, udostępnionego mu przez autora ${ }^{25}$.

W 90\% tekst Dziejów ojczystych ze szczególnym uwzględnieniem historii Galicji - taki tytuł nadał Chyliński swej przeróbce dzieła Bobrzyńskiego - pokrywał się z ich pierwowzorem, tj. Dziejami Polski $w$ zarysie ${ }^{26}$. Chyliński wnosił do tekstu Bobrzyńskiego, dotyczącego dziejów Polski do 1772 r., niewiele zmian, czasami coś opuścił, innym razem uzupełnił wykład o nowe, przemawiające do wyobraźni uczniów fakty historyczne. Starał się przy tym nie naruszyć fundamentów koncepcji historiozoficznej Bobrzyńskiego. Nie zawsze mu się to udawało. Potrzeby dydaktyczne, związane z patriotycznym wychowaniem młodzieży, skłaniały go niekiedy do osłabienia pesymistycznej wymowy oryginalnej wersji Dziejów Polski $w$ zarysie. Postępował jednak w tym zakresie bardzo ostrożnie. Świadczy o tym fragment Dziejów ojczystych poświęcony wydarzeniom lat 1768-1772.

Chyliński informował uczniów m.in. o tym, że szlachta w latach 1767-1768 była oburzona polityką rosyjską „do żywego", a zawiązana przez nią w Barze konfederacja „wkrótce we wszystkich prowincjach żywy odgłos znalazła” ${ }^{27}$. Szczególnie wymowne było jednak stwierdzenie, że konfederacja barska oparta była na „szlachetnych pobudkach"28. Bobrzyński nigdy czegoś takiego nie napisał, nawet w późniejszych wydaniach swej syntezy wypowiadał się na ten temat w sposób bardziej powściągliwy.

I jeszcze jedna dość istotna zmiana, jaką wprowadził Chyliński do wykładu Bobrzyńskiego; otóż odstąpił od dość obiektywnej narracji autora Dziejów Polski $w$ zarysie dotyczącej udziału Austrii w działaniach zmierzających do podziału Rzeczypospolitej. Wybielał politykę tego zaborcy, podtrzymując mit o tym, że dla „Austrii a osobliwie dla panującej w niej cesarzowej szlachetnej Marii Teresy, myśl gwałtownego podziału Polski była zawsze wstrętną"29. Wychodząc naprzeciw polityce historycznej rządzącego Galicją obozu, Chyliński przekonywał, że Austria zmieniła zdanie, kiedy nabrała przekonania, że „Prusy i Rosja i tak Polskę rozbiorą, a przez to siły swe ogromnie zwiększą i nad Austrią osiągną przewagę". Dopiero wówczas „ustąpiła Maria Teresa po długiej walce wewnętrznej i postanowiła zajęciem części polskiego kraju przeciw Rosji i Prusom się zabezpieczyć”30.

25 Por. Dzieje ojczyste ze szczególnym uwzględnieniem historii Galicji. Dzieło prof. Uniw. Jagiell. M. Bobrzyńskiego do użytku wyższych klas szkót średnich zastosowat Michał Chyliński, Kraków 1879. Przedmowa do tego dziełka nosi datę: 1 I 1879 r.

26 Trzeba tu zaznaczyć, że Chyliński uzupełnił wykład Bobrzyńskiego o krótkie omówienie dziejów Polski (głównie Galicji) w latach 1772-1879.

${ }^{27}$ Dzieje ojczyste ze szczególnym uwzględnieniem historii Galicji..., s. 283.

28 Tamże.

29 Tamże, s. 284. Bobrzyński wypowiadał się na ten temat znacznie ostrożniej.

30 Tamże. 
Oczywistą jest rzeczą, że negatywna ocena wydarzeń lat 1768-1772 pozostawała w ścisłym związku z prowadzoną przez konserwatystów krakowskich krytyką liberum conspiro. Chyliński potępiał je równie mocno jak Bobrzyński, a wcześniej Szujski i Kalinka. Chodziło im wszystkim o stanowcze zerwanie z konspiracyjną i powstańczą tradycją, stanowiącą śmiertelne zagrożenie dla ugodowej wobec Austrii polityki stańczyków.

Stan ten utrzymywał się długo. Wiele jednak wskazuje na to, że polityka historyczna konserwatystów krakowskich ${ }^{31}$ zaczęła stopniowo ewoluować. Początki tego zjawiska można datować na połowę lat 80 . Komplikująca się sytuacja międzynarodowa powodowała, że w społeczeństwie polskim ponownie zaczęły odżywać aspiracje niepodległościowe, co siłą rzeczy musiało prowadzić do częściowej rehabilitacji polskiego wysiłku zbrojnego doby rozbiorów i okresu porozbiorowego. Stańczycy wciąż się temu przeciwstawiali, ale i oni - chcąc utrzymać swe wpływy w społeczeństwie - musieli w jakiejś mierze wyjść naprzeciw tej tendencji, złagodzić nieco swój pogląd na konspiracje i powstania narodowe.

Na gruncie szkolnej edukacji historycznej znalazło to swój wyraz - bardzo zresztą nieśmiały - w opracowanym przez Anatola Lewickiego Zarysie historii Polski i krajów ruskich z niq połaczonych. Pierwsze wydanie tej książki, przeznaczonej dla uczniów wyższych klas galicyjskich szkół średnich, ujrzało światło dzienne w Krakowie w 1884 r. Opracowanie to - wielokrotnie z czasem poprawiane i uzupełniane - miało wiele wydań, było niewątpliwie najlepszym, najwyżej cenionym podręcznikiem historii ojczystej w autonomicznej Galicji; używano go długo, także w innych dzielnicach kraju, w Polsce Niepodległej, a nawet później (na emigracji) jeszcze po 1945 r. Działo się tak pomimo wielu krytycznych uwag, jakich temu opracowaniu nigdy nie szczędzono.

Jego autor - Anatol Lewicki (1841-1899) ${ }^{32}$ był Rusinem silnie związanym z Polską i polskością. Ukończył Uniwersytet Lwowski, przez jakiś czas był nauczycielem w gimnazjum przemyskim, później uczył historii i geografii w jednym z gimnazjów lwowskich, publikując jednocześnie wiele prac poświęconych średniowiecznym dziejom Polski. Od 1883 r. aż do śmierci zajmował na Uniwersytecie Jagiellońskim katedrę historii Austrii; jednocześnie wykładał w działających w Krakowie półwyższych szkołach żeńskich. Nie brał czynnego udziału w życiu politycznym, ale sympatyzował $\mathrm{z}$ konserwatystami krakowskimi i popierał ich ugodową politykę wobec Austrii.

31 Jako pierwsza systematyczne badania nad tym problemem podjęła M. Hoszowska, „Polityka historyczna" stańczyków, w: Historia, mentalność, tożsamość. Miejsce i rola historii oraz historyków w życiu narodu polskiego i ukraińskiego w XIX i XX wieku, red. J. Pisulińska, P. Sierżęga, L. Zaszkilniak, Rzeszów 2008, s. 203-217.

32 Por. W. Czermak, Anatol Lewicki (1841-1899). Wspomnienie pośmiertne, Kraków 1899; J. Mitkowski, Lewicki Anatol (1841-1899), w: Polski słownik biograficzny, t. 17, Wrocław 1972, s. 224-225; J. Łosowski, Anatol Lewicki, Przemyśl 1981. 
Jak już wyżej wspomnieliśmy, Zarys historii Polski i krajów ruskich z nia połaczonych uznawany był i jest za podręcznik szkolny, jest to o tyle uzasadnione, że taką właśnie rolę pełnił przez długie dziesięciolecia ${ }^{33}$. Po ponownej analizie tego dzieła dochodzimy jednak obecnie do wniosku, że było ono również parasyntezą dziejów Polski, opartą - zasadniczo rzecz biorąc - na historiozofii szkoły krakowskiej, ale wykazującą także pewne cechy szczególne, znajdujące m.in. swój wyraz w wyraźnym złagodzeniu krytyki Rzeczypospolitej, odejściu od skrajnego pesymizmu, tak charakterystycznego nie tylko dla syntezy Bobrzyńskiego, ale także Historii polskiej Szujskiego, na rzecz bardziej wyważonego spojrzenia na przeszłość narodową. Szczegółowa analiza Historii Polski i krajów ruskich z nia połączonych prowadzi do wniosku, że parasynteza ta odbiegała od wielu ocen Bobrzyńskiego, nawiązywała natomiast do niewątpliwie bardziej umiarkowanych koncepcji Szujskiego $\mathrm{z}$ lat 1864-1866. Widać to bardzo wyraźnie m.in. w nakreślonym przez Lewickiego obrazie konfederacji barskiej.

Lewicki poświęcił jej kilkakrotnie więcej miejsca niż Bobrzyński, omówił ją nawet nieco szerzej niż Szujski w $1880 \mathrm{r} .^{34} \mathrm{~W}$ wyodrębnionym specjalnie podrozdziale, zatytułowanym Konfederacja barska, wymienił z nazwiska blisko 60 osób, podał także kilkanaście dat dotyczących ważniejszych faktów ${ }^{35}$. Dość szczegółowo relacjonował wydarzenia polityczne, a także przebieg walk z wojskami rosyjskimi. Dużą wagę przywiązywał również do sytuacji międzynarodowej i działań dyplomatycznych podejmowanych przez konfederatów.

Konfederacja barska była dla Lewickiego wydarzeniem ważnym, zasługującym na szczególną uwagę. Nawiązując do Lelewela, nazywał ją „powstaniem”. Terminem tym czasami posługiwał się także (w 1866 r.) Szujski, Lewicki stosował go jednak znacznie częściej, w sposób konsekwentny.

Genezę konfederacji barskiej wiązał z „poniewieraniem narodu” polskiego przez Rosję. Jej twórcami była „garstka przeważnie drobnej szlachty”. Lewicki z szacunkiem odnosił się do motywów jej działań, podnosił wszakże, iż były one

${ }^{33}$ O podręczniku Lewickiego pisali m.in.: W. Smoleński, Nauczanie historii polskiej, w: tenże, Pisma historyczne, t. 3, Kraków 1901, s. 452-457; H. Pohoska, Dydaktyka historii, wyd. 2, Warszawa 1957, s. 289-290; W. Zwolska, Podręczniki historii w gimnazjach galicyjskich w latach 1867-1914, „Zeszyty Naukowe Uniwersytetu Łódzkiego. Seria 1. Nauki Humanistyczno-Społeczne” 1972, nr 86, s. 39; J. Maternicki, Dydaktyka historii w Polsce 1773-1918, Warszawa 1974, s. 97-100; Z. Michalik, Na drodze ku integralnej wizji dziejów Polski. Podręczniki szkolne przełomu XIX i XX w., „Przegląd Humanistyczny" 1981, nr 1-2, s. 236-242; K. Gawroński, Wplyw krakowskiej szkoły historycznej na galicyjskie podręczniki historii Polski doby pozytywizmu, „Przegląd Humanistyczny” 1981, nr 6, s. 136-138; C. Majorek, Historia utylitarna i erudycyjna. Szkolna edukacja historyczna w Galicji (1772-1918), Warszawa 1990, s. 271, 330-332.

${ }^{34}$ W drugim wydaniu parasyntezy Lewickiego (1888) wydarzenia lat 1768-1772 omówione zostały na 6 stronach. Jak już wiemy, Bobrzyński w znacznie obszerniejszym opracowaniu poświęcił im zaledwie niepełną stronę.

35 Por. A. Lewicki, Zarys historii Polski i krajów ruskich z nią połączonych, wyd. 2, Kraków 1888, s. 258-293. 
przedwczesne (z wywodów autora wynika, że należało czekać do zapowiedzianego wyjścia wojsk rosyjskich z terytorium Rzeczypospolitej). Programem konfederatów była walka „za wiarę, wolność i dawne prawa, przeciw obcej przemocy”"36.

Podobnie widzieli to wcześniej Szujski i Bobrzyński. Za nimi Lewicki powtarzał też, że związek konfederacki „nie był wolny od wad i przesądów przeszłości, a skierowany był nie tylko przeciw Rosji, ale i przeciw królowi, któremu wszystko zło przypisywano. Dlatego mimo piękne rysy heroizmu i poświęcenia, jakimi się wsławił, nie osiągnął celu" ${ }^{\text {"37. }}$.

Lewicki, podobnie jak wcześniej Szujski i Bobrzyński, przywiązywał dużą wagę do relacji konfederatów z królem. Wyrzucał im, że nie chcieli „zrozumieć korzyści, jakie by konfederacja odniosła, gdyby król na jej czele stanął”. Dowodził, że: „W miarę postępu konfederacji król z Czartoryskimi przechylał się na jej stronę i myślał już przystąpić do niej, gdy generalność popchnięta przez Dumourieza i ludzi przewrotnych, ogłosiła akt bezkrólewia, a przez to króla rzuciła na nowo w objęcia Rosji (1770) [podkr. J.M.]”38. W ten sposób, „przez niepolityczne i niesprawiedliwe postępowanie z królem”, konfederaci „sami sobie zaszkodzili”39. Lewicki potępiał również porwanie króla (1771), przekonywał: „Takie postępowanie pozbawiło konfederację tych sympatii, jakie u wielu rządów europejskich posiadała" ${ }^{2}$.

Autor Zarysu historii Polski i krajów ruskich $z$ nia połączonych przywiązywał wielką wagę do sytuacji międzynarodowej i ówczesnych działań dyplomatycznych. Przypominał, że: „Liczono na pomoc poręczycieli traktatów oliwskiego i karłowickiego: Austrii, Francji i Turcji”. Początkowo udało się w jakiejś mierze ją uzyskać, później jednak sytuacja uległa niekorzystnej zmianie. Przyczyny tego zjawiska tkwiły - zdaniem Lewickiego - nie tylko w błędach konfederatów, ale także w ewolucji ówczesnej sytuacji międzynarodowej, w „stosunkach dyplomatycznych". Autor przypominał tu m.in. konsekwencje porażek Turcji w wojnie z Rosją, a także upadek przychylnego konfederatom rządu Etienne’a-François de Choiseula we Francji. Pisząc o tym drugim wydarzeniu, zaznaczał, że: „Wprawdzie Francja nie przestała i teraz wspierać konfederacji, lecz stawała się obojętniejszą, a co najważniejsze, zawiodła w chwili stanowczej" ${ }^{31}$. Duże, a może nawet jeszcze większe znaczenie przywiązywał do „wielkich postępów Rosji w wojnie tureckiej”. Wytworzyły one w Europie „sytuację polityczną, która ostatecznie spowodowała rozbiór Polski i upadek konfederacji barskiej”22.

\footnotetext{
36 Tamże, s. 288.

37 Tamże.

38 Tamże, s. 291.

39 Tamże.

40 Tamże.

41 Tamże.

42 Tamże.
} 
O ile wcześniejsze opinie Lewickiego, a więc jego generalne oceny konfederacji były - zasadniczo rzecz biorąc - zgodne z werdyktami Bobrzyńskiego, o tyle ostatnie z przytoczonych wyżej zdań zdają się świadczyć, iż w niektórych sprawach zajmował stanowisko odmienne. Na przyczyny klęski konfederatów patrzył inaczej niż autor Dziejów Polski w zarysie. Przywiązywał większą niż Bobrzyński wagę do czynników zewnętrznych; nie twierdził, że odegrały one rolę decydującą, ale uznawał je za bardzo istotne. Zajmując takie stanowisko, w jakiejś mierze brał konfederatów w obronę, częściowo usprawiedliwiał ich porażkę.

Opisując przebieg walk z wojskami rosyjskimi, odnotowywał nie tylko ponoszone klęski, ale i zwycięstwa. Przypominał m.in. „świetną obronę Częstochowy, gdzie Kazimierz Pułaski zniszczył prawie zupełnie oblegający go korpus Drewicza”. Przypominał też sukcesy konfederatów w ich walkach z wojskami królewskimi, m.in. to, że „Zaremba pobił na głowę Ksawerego Branickiego pod Widawą" ${ }^{3}$. Podkreślał żywotność konfederatów, którzy pomimo poniesionych klęsk, w latach 1770 i 1771 utrzymywali powstanie „w pełnej sile, tak w Wielkiej, jak i Małej Polsce”44.

Lewicki patrzył na konfederację znacznie bardziej życzliwie niż Bobrzyński. Wspominając jej początki, zaznaczył, że w toczonych wówczas walkach podjazdowych wiele było „czynów bohaterskich”, za „pierwszych bohaterów tych walk” uznawał braci Kazimierza i Franciszka Pułaskich ${ }^{45}$.

Daleki był jednak od apologii konfederatów barskich. Podnosił m.in., że długo brakowało im „jednolitego kierownictwa”. „Dowódcy partykularni” w Wielkopolsce, na Mazowszu i na Litwie „często niezgodni między sobą, szkodzili sobie nawzajem”46. Miał także sporo zastrzeżeń do „przywódców związku”"47.

Sytuacja ta uległa pewnej poprawie po utworzeniu w Białej Generalności. Lewicki podkreślał, że doszło do tego dzięki życzliwości Austrii. W ogóle był pełen uznania dla polityki austriackiej, podtrzymywał mit o dobrej, wyjątkowo życzliwej Polsce cesarzowej Marii Teresie. Otóż, jego zdaniem, jeszcze przed 1768 r. patrzyła ona „niechętnie na przemoc Rosji w sąsiedniej Polsce. Maria Teresa już w r. 1767 chciała wysłać wojska do Polski, aby uwolnić króla i rz[ecz]p[ospo]litą od gwałtów Repnina” ${ }^{\text {" }}$. Nie doszło do tego, bo król pruski Fryderyk zagroził Austrii „wojną, gdyby jej armia do Polski wkroczyła" ${ }^{49}$. Austria udzieliła konfederacji barskiej „bezpośredniej pomocy”, dając „bezpieczne schronienie” dla jej Generalności na Węgrzech. Później długo przeciwstawiała się polityce Fryderyka II dążącego do podziału Polski. W 1771 r. - podnosił Lewicki - „Maria Teresa, licząc na pomoc

\footnotetext{
43 Tamże, s. 290.

44 Tamże, s. 291.

45 Tamże, s. 289.

46 Tamże.

47 Por. tamże.

48 Tamże, s. 290.

49 Tamże, s. 292-293.
} 
sprzymierzonej Francji, gotowała się z orężem sprzeciwić podziałowi, a z Turcją zawarła nawet przymierze zaczepno-odporne w którym przyznano Turcji zwrot Mołdawszczyzny i zawarowano niepodległość Polski”"50. Ostatecznie jednak, obawiając się, że Prusy mogą się połączyć z Rosją przeciwko Austrii, także i ona podpisała konwencję podziałową. Maria Teresa zgodziła się na rozbiór Polski „ze wstrętem” - podkreślał Lewicki. Jego prohabsburskie stanowisko, widoczne w stosunku nie tylko do tej, ale także wielu innych kwestii historycznych, stało się powodem kąśliwej uwagi Władysława Smoleńskiego, że podręcznik historyka krakowskiego „służyć może tylko ku nauce młodzieży galicyjskiej i ... pożytkowi Austrii”"51. Było w tej opinii sporo racji, ale też i wiele przesady. Warto przy sposobności zauważyć, że prohabsburskie stanowisko zajmowali także Bobrzyński i Szujski, Lewicki różnił się od nich tym, że wypowiadał się na temat rzekomo propolskiej polityki Austrii z większym emocjonalnym zaangażowaniem.

Być może przynajmniej po części wynikało to z pochodzenia historyka. Rusini (Ukraińcy) galicyjscy odnosili się do Austrii z reguły z większą życzliwością i wdzięcznością niż Polscy, nawet ci, którzy współdziałanie z Wiedniem uznawali za podstawowy dogmat polityki polskiej w tej dzielnicy.

Omówienie poglądów Lewickiego zakończmy kilkoma uwagami dotyczącymi jego zapatrywań na rzeź humańską w 1768 r. Rusin Lewicki patrzył na nią oczyma Polaka. W tym zakresie trzymał się ściśle linii interpretacyjnej wytyczonej przez Szujskiego i Bobrzyńskiego. „Na Ukrainie - pisał - wrzało nieustannie z powodu napadów rosyjskich »hajdamaków « i zaciekłej propagandy schizmatyckiej. Poruszenie sprawy dyzunickiej w konfederacji radomskiej podnieciło na nowo tlejący ogień i dzikie instynkty ciemnego ludu wylały się w okropnej rzezi na wszystko, co nie wyznawało schizmy, na szlachtę, księży i żydów"52. Autor twierdził, że głównymi jej sprawcami byli „poddani rosyjscy”: Michaił Znaczko Jaworski i Maksym Żeleźniak, sugerował w ten sposób, że odpowiedzialność za popełnione zbrodnie ponosiła głównie Rosja. Miał to potwierdzać fakt, że wymienieni wyżej sprawcy po stłumieniu rzezi przez Rosje „nie ponieśli żadnej kary”. Warto też odnotować, że Lewicki z uznaniem odnosił się do działań Piotra Kreczetnikowa i Józefa Stempkowskiego (w oryginale: Stępkowskiego), którzy „srogimi egzekucjami” położyli kres rzezi humańskiej. Zgodnie też z Szujskim i Bobrzyńskim, Lewicki twierdził, że „okropna rzeź” humańska „sparaliżowała ruchy konfederatów w południowo-wschodnich krajach rz[eczy]p[ospo]litej"53.

Zamykając moje rozważania poświęcone poglądom historyków szkoły krakowskiej na konfederację barską, pragnę stwierdzić, że choć we wszystkich przypadkach były one krytyczne, to jednak stopień owego krytycyzmu był dość

\footnotetext{
50 Tamże, s. 293.

51 W. Smoleński, dz. cyt., s. 457.

52 A. Lewicki, dz. cyt., s. 289.

53 Tamże.
} 
zróżnicowany. Szczególnie wyostrzony był on w Bobrzyńskiego Dziejach Polski $w$ zarysie (1879) oraz w drugiej syntezie Szujskiego (1880). Przyczyny tego stanu rzeczy, jak pamiętamy, tkwiły w napiętej sytuacji politycznej w Galicji w drugiej połowie lat 70. XIX w. Renesans dążeń niepodległościowych społeczeństwa, wywołany komplikacjami w sytuacji międzynarodowej, skłonił wówczas stańczyków do zaostrzenia krytyki liberum conspiro, a więc konspiracji i powstań narodowych.

Bardziej wyważony charakter krytyka ta miała w pierwszych latach po klęsce powstania styczniowego i w połowie lat 80 . XIX w. W przypadku ocen konfederacji barskiej formułowanych w latach 1865-1866 znajduje to swój wyraz w pierwszej syntezie Szujskiego. Pisząc czwarty tom swych Dziejów Polski (1866) tuż po upadku powstania styczniowego, musiał się on $\mathrm{w}$ jakiejś mierze liczyć $\mathrm{z}$ wciąż żywymi jeszcze sympatiami społeczeństwa polskiego dla tych, którzy podjęli nierówną walkę z zaborcą. Sprawa była zbyt bolesna, aby można było o niej pisać w sposób tak krytyczny, jak to miało miejsce później (poczynając od Teki Stańczyka w 1869 r.). W 1866 r. Szujski nie odwrócił się jeszcze całkowicie od tradycji powstańczej, patrzył na poczynania konfederatów krytycznie, ale też wykazywał wobec nich sporo empatii. Zaostrzył jej krytykę pod koniec lat 60., zwłaszcza zaś w drugiej połowie lat 70. XIX w. Najbardziej krytyczne stanowisko wobec wydarzeń lat 1768-1772 zajął Bobrzyński, ale i on - co prawda tylko nieznacznie - ocieplił obraz konfederacji barskiej w kolejnych wydaniach swej syntezy.

Najbardziej chyba interesujący przypadek to obraz konfederacji barskiej nakreślony w 1884 r. przez Lewickiego. Powrócił on do niektórych spostrzeżeń i ocen Szujskiego z 1866 r. Nie szczędził konfederacji krytyki, ale jednocześnie starał się ukazać jej jaśniejsze strony. Cieplejszy - w porównaniu do Bobrzyńskiego i Szujskiego z 1880 r. - stosunek tego historyka do konfederatów wynikał, jak się wydaje, nie tylko z potrzeby kształtowania uczuć patriotycznych młodego pokolenia Polaków (rzecz zrozumiała w przypadku podręcznika szkolnego), ale także z ewolucji polityki historycznej stańczyków, która poczynając od połowy lat 80. XIX w. zaczęła stopniowo łagodzić bezwzględne oceny walk niepodległościowych XIX w.

Reasumując to wszystko, można stwierdzić, że zapatrywania historyków szkoły krakowskiej na konfederację barską ulegały ewolucji i wykazywały sporo cech indywidualnych. Ich fundament był jednak niewzruszony: uznawano ruch barski za zjawisko pod względem politycznym szkodliwe, pozostające w bezpośrednim związku z I rozbiorem Rzeczypospolitej. W skrajnych przypadkach (Bobrzyński w 1879 i Szujski w 1880 r.) konfederacja barska była traktowana jako przykład wyniszczającej anarchii, prowadzącej prostą drogą do upadku państwa. Lewicki oceniał ją jednak nieco łagodniej, wskazywał na to, że konfederaci wykazali się wprawdzie brakiem politycznego rozsądku, ale kierowali się szlachetnymi pobudkami (obrona niepodległości), w boju z wojskami rosyjskimi wykazali zaś wielką waleczność i heroizm. 


\section{Bibliografia}

W.M. Bartel, Michat Bobrzyński (1849-1935), w: Spór o historyczna szkołę krakowską. W stulecie Katedry Historii Polski UJ 1869-1969, red. C. Bobińska, J. Wyrozumski, Kraków 1972, s. 145-189

A. Beaupré, Chyliński Michał (1856-1925), w: Polski słownik biograficzny, t. 4, Kraków 1938, s. 13

M. Bobrzyński, Dzieje Polski w zarysie, wyd. 3, Warszawa 1881

M. Bobrzyński, Dzieje Polski w zarysie, t. 2, wyd. 4 uzup., Warszawa 1927

M. Bobrzyński, Dzieje Polski w zarysie, oprac. i wstęp M.H. Serejski, A.F. Grabski, Warszawa 1974

M. Bobrzyński, Kilka słów o najnowszym ruchu na polu naszego dziejopisarstwa, w: Historycy o historii. Od Adama Naruszewicza do Stanistawa Kętrzyńskiego 1775-1918, t. 1, oprac. M.H. Serejski, Warszawa 1963, s. 149-168

M. Bobrzyński, Przedmowa do drugiego wydania „Dziejów Polski w zarysie”, w: tenże, Szkice i studia historyczne, t. 1, Kraków 1922

E. Cesarz-Maternicka, Chłopi i sprawa chłopska w „Dziejach Polski” Michała Bobrzyńskiego, w: Historia, społeczeństwo, wychowanie, red. J. Maternicki, M. Hoszowska, P. Sierżęga, Rzeszów 2003, s. 137-149

W. Czermak, Anatol Lewicki (1841-1899). Wspomnienie pośmiertne, Kraków 1899

Dzieje ojczyste ze szczególnym uwzględnieniem historii Galicji. Dzieło prof. Uniw. Jagiell. M. Bobrzyńskiego do użytku wyższych klas szkół średnich zastosował Michał Chyliński, Kraków 1879

S. Estreicher, Michał Bobrzyński, Warszawa 1936 (odb. z „Przeglądu Współczesnego”)

K. Gawroński, Wpływ krakowskiej szkoły historycznej na galicyjskie podręczniki historii Polski doby pozytywizmu, „Przegląd Humanistyczny” 1981, nr 6, s. 136-138

A.F. Grabski, Jeszcze o sporach wokót „Dziejów Polski w zarysie”, w: tenże, Perspektywy przeszłości. Studia i szkice historiograficzne, Lublin 1983, s. 279-340

K. Grzybowski, Szkoła historyczna krakowska. Michał Bobrzyński (1849-1935), w: Studia z dziejów Wydziału Prawa Uniwersytetu Jagiellońskiego, red. M. Patkaniowski, Kraków 1964, s. 163-186

M. Handelsman, Bobrzyński jako uczony, „Przegląd Historyczny” 33, 1936, nr 1, s. 341-361

M. Hoszowska, „Polityka historyczna” stańczyków, w: Historia, mentalność, tożsamość. Miejsce i rola historii oraz historyków w życiu narodu polskiego i ukraińskiego w XIX i XX wieku, red. J. Pisulińska, P. Sierżęga, L. Zaszkilniak, Rzeszów 2008, s. 203-217

W. Kaute, Synteza dziejów Polski Michała Bobrzyńskiego, Katowice 1993

S. Kieniewicz, Tło historyczne „Dziejów Polski” Bobrzyńskiego, „Przegląd Historyczny” 37, 1947 [1948], s. 343-356

B. Klassa, Obraz szlachty w „Dziejach Polski w zarysie” Michała Bobrzyńskiego, w: Klio polska. Studia i materiaty z dziejów historiografii polskiej, t. 4, red. A. Wierzbicki, Warszawa 2009, s. 57-79

B. Krzemieńska-Surowiecka, Polemika wokół „Dziejów Polski w zarysie” Michała Bobrzyńskiego (w latach 1879-1890), „Zeszyty Naukowe Uniwersytetu Łódzkiego. Seria 1. Nauki Humanistyczno-Społeczne" 1956, nr 4, s. 107-130

A. Lewicki, Zarys historii Polski i krajów ruskich z nia połaczonych, wyd. 2, Kraków 1888

W. Łazuga, Michał Bobrzyński. Myśl historyczna a działalność polityczna, Warszawa 1982

W. Łazuga, Ostatni stańczyk. Michał Bobrzyński - portret konserwatysty, Poznań b.d.w. (wyd. 2, Toruń 2005)

J. Łosowski, Anatol Lewicki, Przemyśl 1981

C. Majorek, Historia utylitarna i erudycyjna. Szkolna edukacja historyczna w Galicji (1772-1918), Warszawa 1990

J. Maternicki, Dydaktyka historii w Polsce 1773-1918, Warszawa 1974

J. Maternicki, Historia i życie narodu. Poglądy i postawy historyków polskich XIX i XX w., Rzeszów 2009

J. Maternicki, Joachim Lelewel i Józef Szujski: wizje konfederacji barskiej, w: Спільна спадщина. Річ Посполита обох народів в польській і украӥнській історичній думиі XIX і XX cm. / Wspólne 
dziedzictwo. Rzeczpospolita Obojga Narodów w polskiej i ukraińskiej myśli historycznej XIX i XX w., red. W. Telwak, L. Łazurko, P. Sierżęga, Chersoń 2019, s. 77-104

J. Maternicki, Michał Bobrzyński wobec „idei zachodniej”, „Przegląd Humanistyczny” 1992, nr 2, s. 79-96 (toż w: tenże, Historia jako dialog. Studia i szkice historiograficzne, Rzeszów 1996, s. 34-54)

J. Maternicki, Michał Bobrzyński wobec tzw. idei jagiellońskiej. Ewolucja pogląów i jej uwarunkowania, „Przegląd Humanistyczny” 1977, nr 12, s. 131-142 (toż w: tenże, Kultura historyczna dawna i wspótczesna. Studia i szkice, Warszawa 1979, s. 144-160)

J. Maternicki, Złote lata historiografii polskiej we Lwowie, Rzeszów 2015

Z. Michalik, Na drodze ku integralnej wizji dziejów Polski. Podręczniki szkolne przełomu XIX i XX w., „Przegląd Humanistyczny” 1981, nr 1-2, s. 236-242

J. Mitkowski, Lewicki Anatol (1841-1899), w: Polski słownik biograficzny, t. 17, Wrocław 1972, s. $224-225$

H. Pohoska, Dydaktyka historii, wyd. 2, Warszawa 1957

A. Puszka, Nauczyciele historii i geografii państwowych szkół średnich w Galicji w okresie autonomii (1868-1914), Lublin 1999

M.H. Serejski, A.F. Grabski, M. Bobrzyński i jego „Dzieje Polski w zarysie”, w: M. Bobrzyński, Dzieje Polski w zarysie, oprac. i wstęp M.H. Serejski, A.F. Grabski, Warszawa 1974, s. 5-34

A. Skrzypek, Michał Bobrzyński jako organizator nauki i wydawca źródeł, „Kwartalnik Historyczny” 85,1977 , nr 3, s. 643-656

W. Smoleński, Nauczanie historii polskiej, w: tenże, Pisma historyczne, t. 3, Kraków 1901, s. 452-457

W. Zwolska, Podręczniki historii w gimnazjach galicyjskich w latach 1867-1914, „Zeszyty Naukowe Uniwersytetu Łódzkiego. Seria 1. Nauki Humanistyczno-Społeczne” 1972, nr 86, s. 27-45

\section{The Bar Confederation in the views of historians from the Kraków school of history. Michał Bobrzyński and Anatol Lewicki}

The way in which historians from the 'Kraków school' of history viewed the Bar Confederation remained closely related to their interpretation of Polish history in general and especially to their criticism of what they defined as liberum conspiro. Their respective views of the movement, showing some specific characteristics, evolved over time. The most severe criticism of the Bar Confederation was expressed by M. Bobrzyński who, in 1879, condemned it in the strongest possible terms. In the later editions of his Dzieje Polski w zarysie, he offered only slightly less critical accounts of the movement, still treating it as an instance of the devastating anarchy the country was plunged in. Although A. Lewicki also pointed out the Confederates' lack of political skills, he showed more understanding for their efforts. In the 1884 handbook, intended for high school students, he aimed to unite political education with the youth's patriotic upbringing, emphasising the Bar Confederates' noble motives, bravery and dedication. Lewicki's views were linked with the direction in which the politics of history pursued by the Kraków conservatives began to evolve in the mid-1880s.

Jerzy Maternicki - prof. dr hab., prof. em. Uniwersytetu Rzeszowskiego, badacz dziejów historiografii polskiej XIX i XX w., historyk i teoretyk kultury historycznej, dydaktyk historii. W ostatnim dwudziestoleciu opublikował m.in. następujące książki: Pogranicza historii. Studia i szkice, Rzeszów 2011; Walerian Kalinka (1826-1886) i jego badania nad epoka porozbiorowa, Rzeszów 2013; Złote lata historiografii polskiej we Lwowie, Rzeszów 2015; Wanda Moszczeńska (1896-1974) - wspóttwórczyni polskiej historii historiografii, Rzeszów 2017. 